\title{
PENILAIAN PRESTASI KERJA KARYAWAN PTPN III PEMATANGSIANTAR DENGAN METODE SIMPLE ADDITIVE WEIGHTING (SAW)
}

\author{
Agus Perdana Windarto \\ Program Studi Sistem Informasi, STIKOM Tunas Bangsa Pematangsiantar \\ Jln. Jenderal Sudirman Blok A No. 1,2,3 Pematangsiantar \\ agus.perdana@amiktunasbangsa.ac.id
}

\begin{abstract}
Performance appraisal of employees is absolutely done to know the achievements that have been achieved every employee. With achievement appraisal means subordinates get attention from the topics to encourage their passionate work, with reference to the process of honest and objective assessment and there follow-up. Follow-up appraisals enable employees to be promoted, demotivated, cultivated, and rewarded for service. The purpose of this study is to make a decision support system employee performance appraisal employee used to increase the class. This decision support system uses Simple Additive Weighting (SAW) Method. Where the criteria used are Work Attitude Employees, How Employees Work, Employees Work and Employee Duty Day. The sample data used is 5 with different weights on each criterion. This study took a case study of PTPN III Pematangsiantar with the calculation that 0.90 has the highest value according to SAW calculation. The value is in the name of Mr. Syamsul Arifin, SE. Therefore this method can be used to assess employees by entering actual data in the system created and can solve the selection problem in multi-process decision making.
\end{abstract}

Keywords: Simple Additive Weighting, Employees, Achievement, PTPN

\begin{abstract}
Abstrak
Penilaian prestasi karyawan mutlak dilakukan untuk mengetahui prestasi yang telah dicapai setiap karyawan. Dengan penilaian prestasi berarti para bawahan mendapat perhatian dari atasaannya sehingga mendorong mereka bergairah bekerja, dengan acuan proses penilaiannya jujur dan objektif serta ada tindak lanjutnya. Tindak lanjut penilaian memungkinkan karyawan dipromosikan, didemosikan, dikembnagkan, dan balas jasanya dinaikkan. Tujuan penelitian ini adalah untuk membuat sistem pendukung keputusan penilaian prestasi kerja karyawan yang digunakan untuk kenaikan golongan. Sistem pendukung keputusan ini menggunakan Metode Simple Additive Weighting (SAW). Dimana kriteria yang digunakan adalah Sikap Kerja Karyawan, Cara Kerja Karyawan, Hasil Karya Karyawan dan Hari Mangkir Karyawan. Sampel data yang digunakan sebanyak 5 dengan bobot yang berbeda pada setiap kriteria. Penelitian ini mengambil studi kasus PTPN III
\end{abstract}


Pematangsiantar dengan hasil perhitungan bahwa 0,90 memiliki nilai tertinggi menurut perhitungan SAW. Nilai tersebut atas nama bapak Syamsul Arifin, SE. Oleh karena itu metode ini dapat dipergunakan untuk menilai karyawan dengan memasukkan data yang sebenarnya dalam sistem yang dibuat dan dapat menyelesaikan masalah penyeleksian dalam pengambilan keputusan multi proses.

Kata Kunci: Simple Additive Weighting, Karyawan, Prestasi, PTPN

\section{PENDAHULUAN}

Dalam menghadapi arus globalisasi, sumber daya manusia (SDM) memegang peranan yang sangat dominan dalam aktivitas atau kegiatan perusahaan. Berhasil atau tidaknya perusahaan dalam mencapai tujuan yang ditetapkan sebelumnya sangat tergantung pada kemampuan sumber daya manusianya (karyawan) dalam menjalankan tugas-tugas yang diberikan kepadanya. Oleh karena itu, setiap perusahaan perlu memikirkan bagaimana cara yang dapat dilakukan untuk mengembangkan sumber daya manusianya agar dapat mendorong kemajuan bagi perusahaan dan bagaimana caranya agar karyawan tersebut memiliki produktivitas yang tinggi, yang tentunya pimpinan perusahaan perlu memotivasi karyawannya.

Penilaian prestasi karyawan mutlak harus dilakukan untuk mengetahui prestasi yang telah dicapai setiap karyawan. Apakah prestasi penting bagi setiap karyawan dan berguna bagi perusahaan untuk menetapkan tindakan kebijaksanaan selanjutnya? Dengan penilaian prestasi berarti para bawahan mendapat perhatian dari atasaannya sehingga mendorong mereka bergairah bekerja, asalkan proses penilaiannya jujur dan objektif serta ada tindak lanjutnya. Tindak lanjut penilaian memungkinkan karyawan dipromosikan, didemosikan, dikembnagkan, dan balas jasanya dinaikkan. Penilaian prestasi kerjanya oleh manajemen perusahaan akan menghasilkan keluaran (output) yang tinggi serta akan mempertinggi loyalitas (kesetiaan) pada perusahaan. Oleh karena itu, pimpinan harus menyadari pentingnya promosi dalam peningkatan produktivitas yang harus dipertimbangkan secara objektif. Jika pimpinan telah menyadari dan mempertimbangkan, maka perusahaan akan terhindar dari masalah-masalah yang menghambat peningkatan keluaran dan dapat merugikan perusahaan seperti ketidakpuasan karyawan, adanya keluhan, tidak adanya semangat kerja, menurunnya disiplin kerja, tingkat absensi yang tinggi atau bahkan masalah-masalah pemogokan kerja.

Untuk dapat memutuskan imbalan yang sepenuhnya diberikan kepada seorang karyawan atas hasil kerjanya, maka perusahaan harus memiliki sesuatu sistem balas jasa yang tepat. Mekanisme untuk dapat menentukan balas jasa yang pantas bagi suatu prestasi kerja adalah dengan penilaian prestasi kerja dan kompetensi karyawan. Melalui penilaian prestasi kerja akan diketahui seberapa baik Ia telah melaksanakan tugas-tugas yang dibebankan kepadanya, sehingga perusahaan dapat menetapkan balas jasa yang sepantasnya atas prestasi kerja tersebut. Ditambah dengan kompetensi 
karyawan yang kuat merupakan landasan yang sangat berguna untuk membantu perusahaan meningkatkan kinerjanya. Kompetensi sangat diperlukan dalam setiap proses sumber daya manusia. Semakin banyak kompetensi dipertimbangkan, maka semakin meningkat pula kinerjanya. Dari hasil tersebut, perusahaan dapat mengembangkan suatu perencanaan sumber daya manusia secara menyeluruh dalam menghadapi masa depan perusahaan. Perencanaan sumber daya manusia secara menyeluruh tersebut berupa jalur-jalur karir atau promosi-promosi jabatan para karyawannya. Mengingat pentingnya penilaian prestasi kerja karyawan ini maka penulis tertarik untuk melakukan penelitian mengenai "SPK Penilaian Prestasi Kerja Karyawan dengan menggunakan Metode SAW Pada PT. Perkebunan Nusantara III Pematangsiantar”.

\section{METODOLOGI PENELITIAN}

\subsection{Sistem Pendukung Keputusan (SPK)}

Sistem Pendukung Keputusan (SPK) sebagai sistem berbasis komputer yang terdiri dari tiga komponen yang saling berinteraksi, sistem bahasa (mekanisme untuk memberikan komunikasi antara pengguna dan komponen Sistem Pendukung Keputusan lain), sistem pengetahuan (repositori pengetahuan domain masalah yang ada pada Sistem Pendukung Keputusan atau sebagai data atau sebagai prosedur), dan sistem pemrosesan masalah (hubungan antara dua komponen lainnya, terdiri dari satu atau lebih kapabilitas manipulasi masalah umum yang diperlukan untuk pengambilan keputusan) [1].

\subsubsection{Karakteristik Sistem Pendukung Keputusan}

Karakteristik dari sistem pendukung keputusan adalah sebagai berikut:

a. Mendukung pengambilan keputusan untuk membahas masalahmasalah terstruktur, semi struktur, dan tidak terstruktur.

b. Output ditujukan bagi personil organisasi dalam semua tingkatan.

c. Mendukung di semua fase proses pengambilan keputusan: intelegensi, desain, pilihan.

d. Adanya interface manusia atau mesin, dimana manusia (user) tetap mengontrol proses pengambilan keputusan.

e. Menggunakan model-model metematis dan statistik yang sesuai dengan pembahasan.

f. Memiliki kemampuan dialog untuk memperoleh informasi sesuai dengan kebutuhan.

g. Memiliki subsistem-subsistem yang terintegrasi sedemikian rupa sehingga dapat berfungsi sebagai kesatuan sistem.

h. Membutuhkan struktur data komprehensif yang dapat melayani kebutuhan informasi seluruh tingkatan manajemen.

i. Pendekatan easy to use. Ciri suatu sistem pendukung keputusan yang efektif adalah kemudahannya untuk digunakan dan memungkinkan 
keleluasaan pemakai untuk memilih atau mengembangkan pendekatan-pendekatan baru dalam membahas masalah yang dihadapi.

j. Kemampuan sistem untuk beradaptasi secara cepat, dimana pengambil keputusan dapat menghadapi masalah-masalah baru dan pada saat yang sama dapat menanganinya dengan cara mengadaptasikan sistem terhadap kondisi-kondisi perubahan yang terjadi [2].

\subsubsection{Tahap-Tahap Pengambilan Keputusan}

Tahap-tahap Pengambilan Keputusan yaitu:

a. Identifikasi masalah

b. Pemilihan metode

c. Pengumpulan data yang dibutuhkan untuk melaksanakan model keputusan tersebut.

d. Mengimplementasikan model tersebut

e. Mengevaluasi sisi positif dari setiap alternatif yang ada

f. Melaksanakan solusi terpilih [3].

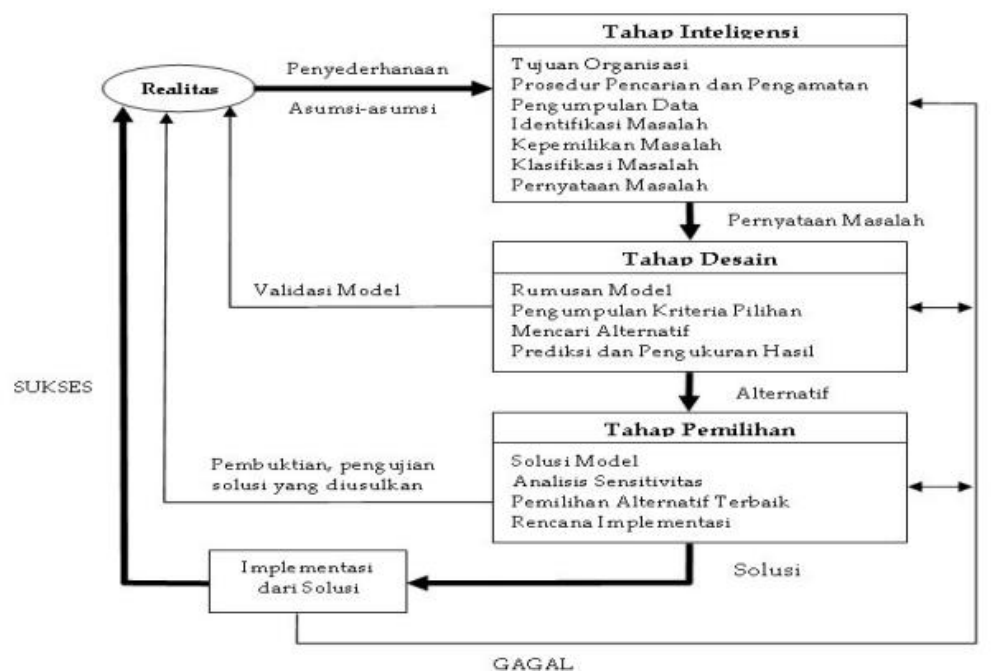

Gambar 1. Tahap Pengambilan Keputusan

(Sumber : Siregar S.M, 2015)

1. Tahap Inteligence

Suatu tahap proses seseorang dalam rangka pengambil keputusan untuk permasalahan yang dihadapi, terdiri dari aktivitas penelusuran, pendeteksian serta proses pengenalan masalah. Data masukan diperoleh, diuji dalam rangka mengidentifikasi masalah.

2. Tahap Design

Tahap proses pengambil keputusan setelah tahap intellegence meliputi proses untuk mengerti masalah, menurunkan solusi dan menguji kelayakan solusi. Aktivitas yang biasanya dilakukan seperti menemukan, mengembangkan dan menganalisa alternatif tindakan yang dapat dilakukan. 
3. Tahap Pemilihan

Pada tahap ini dilakukan proses pemilihan diantara berbagai alternatif tindakan yang mungkin dijalankan. Hasil pemilihan tersebut kemudian diimplementasikan dalam proses pengambilan keputusan [3].

\subsection{Simple Additive Weighting (SAW)}

Metode Simple Additive Weighting (SAW) sering juga dikenal istilah metode penjumlahan terbobot. Konsep dasar metode SAW adalah mencari penjumlahan terbobot dari rating kinerja pada setiap alternatif pada semua atribut. Metode SAW membutuhkan proses normalisasi matriks keputusan (X) ke suatu skala yang dapat diperbandingkan dengan semua rating alternatif yang ada [4].

Formula yang digunakan untuk melakukan normalisasi adalah sebagai berikut:

$\mathrm{R}_{\mathrm{ij}}=\left\{\begin{array}{l}\frac{x_{i j}}{\operatorname{Max} X_{i j}} \text { jika } j \text { adalah atribut keuntungan (benefit) } \\ \frac{\operatorname{Min}_{i j}}{x_{i j}} \text { jika } j \text { adalah atribut keuntungan (cost) } X_{i j}\end{array}\right\}$

Keterangan:

$\mathrm{R}_{\mathrm{ij}} \quad=$ Rating kinerja ternormalisasi dari alternatif Ai pada atribut $\mathrm{Cj}: i=1,2, \ldots, m$ dan $j=1,2, \ldots, n$

Max $\mathrm{X}_{\mathrm{ij}} \quad=$ Nilai terbesar dari setiap kriteria $\mathrm{i}$

Min $\mathrm{X}_{\mathrm{ij}} \quad=$ Nilai terkecil dari setiap kriteria $\mathrm{i}$

$\mathrm{X}_{\mathrm{ij}} \quad=$ Nilai atribut yang dimiliki dari setiap kriteria

Benefit = Jika nilai terbesar adalah terbaik

Cost $\quad=$ Jika nilai terkecil adalah terbaik

Nilai preferensi untuk setiap alternatif $\left(\mathrm{V}_{\mathrm{i}}\right)$ diberikan rumus sebagi berikut:

Keterangan:

$$
V_{I}=\sum_{J=1}^{n} W_{J} r_{i j}
$$

$\mathrm{V}_{\mathrm{i}} \quad=$ Rangking untuk setiap alternatif

$\mathrm{W}_{\mathrm{j}} \quad$ = Nilai bobot rangking (dari setiap alternatif)

$\mathrm{r}_{\mathrm{ij}} \quad=$ Nilai rating kinerja ternormalisasi

Nilai $V_{i}$ yang lebih besar mengindikasikan bahwa alternatif $A$ ilebih terpilih [5]. 


\section{HASIL DAN PEMBAHASAN}

\subsection{Analisa}

Untuk menyelesaikan pengambilan keputusan berdasarkan perhitungan algoritma SAW, hal pertama yang dilakukan adalah Menentukan nilai kriteria $\mathrm{Cj}$ pada suatu set alternatif Ai. Beserta bobot preferensi $(\mathrm{Wj})$ setiap kriteria $\mathrm{Cj}$, berikut kriteria-kriteria yang dibutuhkan dalam pengambilan keputusan :

Tabel 1. Kriteria

\begin{tabular}{llll}
\hline No & Kriteria & Penilaian & Bobot \\
\hline 1 & C1 & Sikap Kerja Karyawan & $30 \%$ \\
2 & C2 & Cara Kerja Karyawan & $30 \%$ \\
3 & C3 & Hasil Karya Karyawan & $20 \%$ \\
4 & C4 & Hari Mangkir Karyawan & $20 \%$ \\
\hline
\end{tabular}

Tabel 2. Standart Nilai Algoritma SAW

\begin{tabular}{cc}
\hline Nilai & Keterangan \\
\hline 5 & Sangat Baik \\
4 & Baik \\
3 & Cukup \\
2 & Kurang Baik \\
\hline
\end{tabular}

Berikut adalah tabel data karyawan yang akan dinilai prestasi kerjanya oleh pimpinan. Penilaian dilakukan langsung oleh pimpinan. Sampel data yang digunakan sebanyak 5 data karyawan yang telah diseleksi. Data tersebut dapat dilihat pada tabel 3:

Tabel 3. Data Karyawan

\begin{tabular}{cclcccc}
\hline No & $\begin{array}{c}\text { Kode } \\
\left(\mathrm{A}_{\mathrm{i}}\right)\end{array}$ & Nama Karyawan & $\begin{array}{c}\text { Sikap Kerja } \\
\text { Karyawan (K1) }\end{array}$ & $\begin{array}{c}\text { Cara Kerja } \\
\text { Karyawan } \\
(\mathrm{K} 2)\end{array}$ & $\begin{array}{c}\text { Hasil Karya } \\
\text { Karyawan } \\
(\mathrm{K} 3)\end{array}$ & $\begin{array}{c}\text { Hari } \\
\text { Mangkir } \\
\text { Karyawan } \\
(\text { K4) }\end{array}$ \\
\hline 1. & A1 & Syamsul arifin, SE & Baik & Sangat Baik & Sangat Baik & Baik \\
2. & A2 & Burhanuddin, SH & Sangat Baik & Cukup & Baik & Baik \\
3. & A3 & Yanti Amelia,Sos & Kurang Baik & Baik & Cukup & Sangat Baik \\
4. & A4 & Eka Prasetia, Amd & Baik & Kurang Baik & Sangat Baik & Cukup \\
5. & A5 & JuniArthur Siahaan,SH & Cukup & Sangat Baik & Kurang Baik & Baik \\
\hline
\end{tabular}

Berikut adalah tabel nilai setelah dikonversi berdasarkan alternatif dan kriteria yang telah terdata. 
Tabel 4. Nilai Setelah Dikonversi pada Algoritma SAW

\begin{tabular}{cccccc}
\hline No & $\begin{array}{c}\text { Kode } \\
\left(\mathrm{A}_{\mathrm{i}}\right)\end{array}$ & $\begin{array}{c}\text { Sikap Kerja } \\
\text { Karyawan } \\
(\mathrm{K} 1)\end{array}$ & $\begin{array}{c}\text { Cara } \\
\text { Kerja } \\
\text { Karyawan } \\
(\mathrm{K} 2)\end{array}$ & $\begin{array}{c}\text { Hasil Karya } \\
\text { Karyawan } \\
(\mathrm{K} 3)\end{array}$ & $\begin{array}{c}\text { Hari } \\
\text { Mangkir } \\
\text { Karyawan } \\
(\mathrm{K} 4)\end{array}$ \\
\hline 1. & A1 & 4 & 5 & 5 & 4 \\
2. & A2 & 5 & 3 & 4 & 4 \\
3. & A3 & 2 & 4 & 3 & 5 \\
4. & A4 & 4 & 2 & 5 & 3 \\
5. & A5 & 3 & 5 & 2 & 4 \\
\hline
\end{tabular}

Proses penilaian dilakukan oleh pimpinan langsung. Setelah bobot alternatif telah disesuaikan dengan nilai kecocokan maka masuk ketahap normalisasi dengan rumus (1).

$$
\begin{aligned}
& r 11=\frac{4}{\max [4,5,2,4,3]}=\frac{4}{5}=0,80 \\
& r 12=\frac{5}{\max [5,3,4,2,5]}=\frac{5}{5}=1,00 \\
& r 13=\frac{5}{\max [5,4,3,5,2]}=\frac{5}{5}=1,00 \\
& r 14=\frac{4}{\max [4,4,5,3,4]}=\frac{4}{5}=0,80 \\
& r 21=\frac{5}{\max [4,5,2,4,3]}=\frac{5}{5}=1,00 \\
& r 22=\frac{3}{\max [5,3,4,2,5]}=\frac{3}{5}=0,60 \\
& r 23=\frac{4}{\max [5,4,3,5,2]}=\frac{4}{5}=0,80 \\
& r 24=\frac{4}{\max [4,4,5,3,4]}=\frac{4}{5}=0,80 \\
& r 31=\frac{2}{\max [4,5,2,4,3]}=\frac{2}{5}=0,40 \\
& r 32=\frac{4}{\max [4,5,2,4,3]}=\frac{4}{5}=0,80 \\
& r 33=\frac{3}{\max [4,4,5,3,4]}=\frac{3}{5}=0,60 \\
& r 34=\frac{5}{\max [4,4,5,3,4]}=\frac{5}{5}=1,00 \\
& r 41=\frac{4}{\max [4,5,2,4,3]}=\frac{4}{5}=0,80 \\
& r 42=\frac{2}{\max [4,5,2,4,3]}=\frac{2}{5}=0,40 \\
& r 43=\frac{5}{\max [4,4,5,3,4]}=\frac{5}{5}=1,00 \\
& r 44=\frac{3}{\max [4,4,5,3,4]}=\frac{3}{5}=0,60 \\
& r 51=\frac{3}{\max [4,5,2,4,3]}=\frac{3}{5}=0,60 \\
& r 52=\frac{5}{\max [4,5,2,4,3]}=\frac{5}{5}=1,00
\end{aligned}
$$




$$
\begin{aligned}
& r 53=\frac{2}{\max [4,4,5,3,4]}=\frac{2}{5}=0,40 \\
& r 54=\frac{5}{\max [4,4,5,3,4]}=\frac{5}{5}=1,00
\end{aligned}
$$

Proses perhitungan normalisasi dilakukan hingga alternatif ke 5 sehingga didapatkan hasil normalisasi seperti dibawah ini:

$$
\mathrm{R}=\left[\begin{array}{llll}
0,80 & 1_{s}, 00 & 1_{s}, 00 & 0,80 \\
1_{s} 00 & 0,60 & 0,80 & 0,80 \\
0,40 & 0,80 & 0,60 & 1,00 \\
0,80 & 0,40 & 1_{s}, 00 & 0,60 \\
0,60 & 1_{s} 00 & 0,40 & 1_{s} 00
\end{array}\right]
$$

Setelah didapat hasil dari normalisasi, maka selanjutnya akan dibuat perkalian matriks (preferensi) untuk mendapatkan perangkingan dari semua alternatif. Diketahui bobot nilai: $\mathrm{W}=[0,300,300,200,20]$

$V_{1}=(0.30)(0.80)+(0.30)(1.00)+(0.20)(1.00)+(0.20)(0.80)=0.90$

$V_{2}=(0.30)(1,00)+(0.30)(0.60)+(0.20)(0.80)+(0.20)(0.80)=0.80$

$\mathrm{V}_{3}=(0.30)(0.40)+(0.30)(0.80)+(0.20)(0.60)+(0.20)(1.00)=0.68$

$V_{4}=(0.30)(0.80)+(0.30)(0.40)+(0.20)(1.00)+(0.20)(0.60)=0.68$

$V_{5}=(0.30)(0.60)+(0.30)(1.00)+(0.20)(0.40)+(0.20)(1,00)=0.76$

Dari proses tersebut diperoleh hasil akhir perhitungan dan perkalian matriks, dapat disimpulkan bahwa yang memiliki nilai tertinggi adalah: Kode (V1) dengan nilai 0,90. Maka, A1 atas nama bapak Syamsul Arifin, SE ditetapkan sebagai karyawan berprestasi berdasarkan perhitungan algoritma SAW.

\subsection{Flowchat Program}

Berikut ini akan dijelaskan tentang flowchart yang dipakai oleh masingmasing algoritma. 


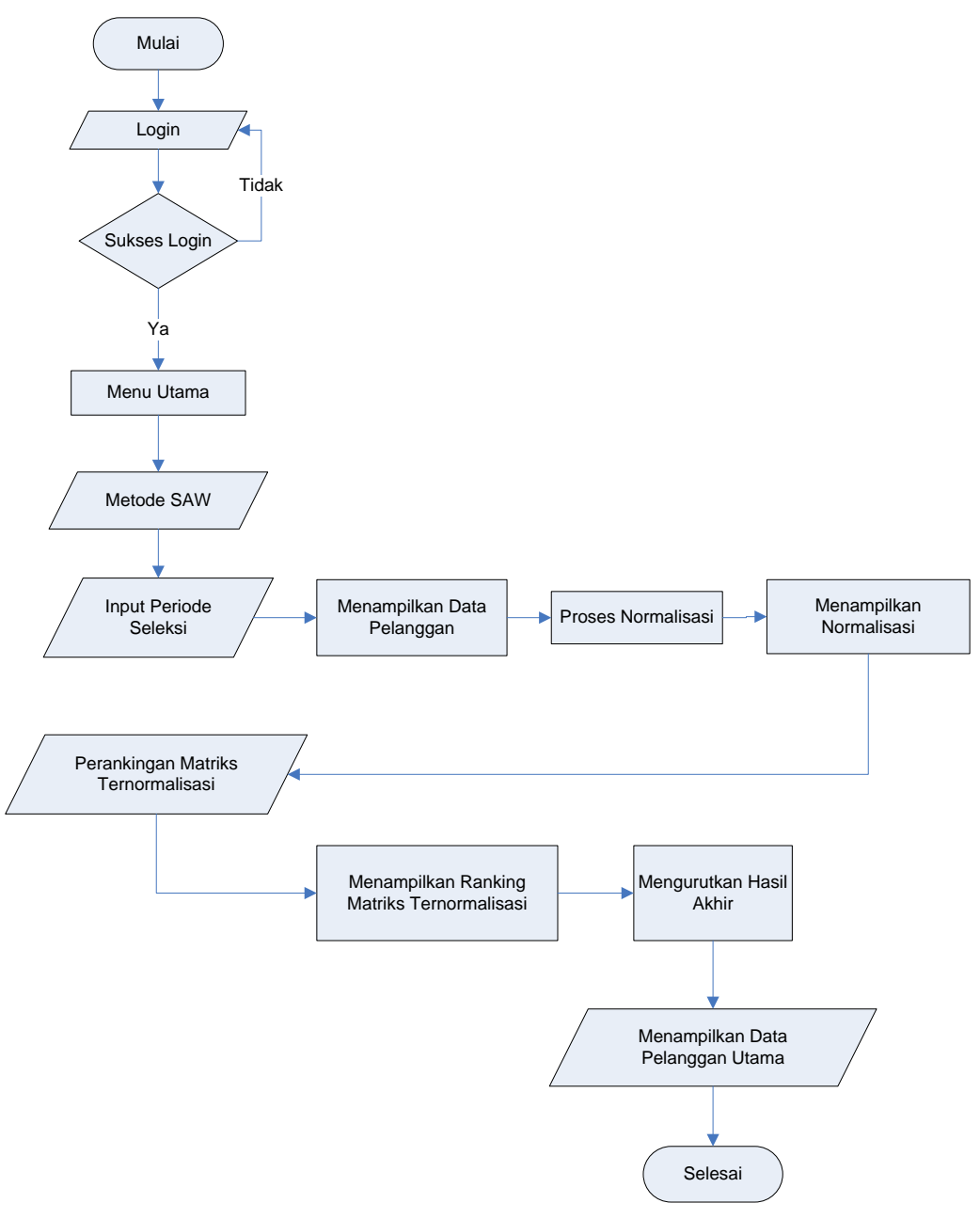

Gambar 1. Flowchart dengan Algoritma SAW

\subsection{Perancangan Unified Modeling Language (UML)}

Perancangan UML (Unified Modeling Language) dimodelkan dalam bentuk alur program seperti, Use Case Diagram, Activity Diagram, dan Class Diagram

\subsubsection{Use Case Diagram}

Use case menunjukkan hubungan interaksi antar aktor dengan Use case didalam suatu sistem yang bertujuan untuk menentukan bagaimana aktor berinteraksi dengan sebuah sistem.

1. Use Case Diagram dengan Algoritma SAW

Berikut ini merupakan Use case diagram pada sistem pendukung keputusan penilaian prestasi kerja karyawan berdasarkan algoritma SAW, adalah sebagai berikut: 


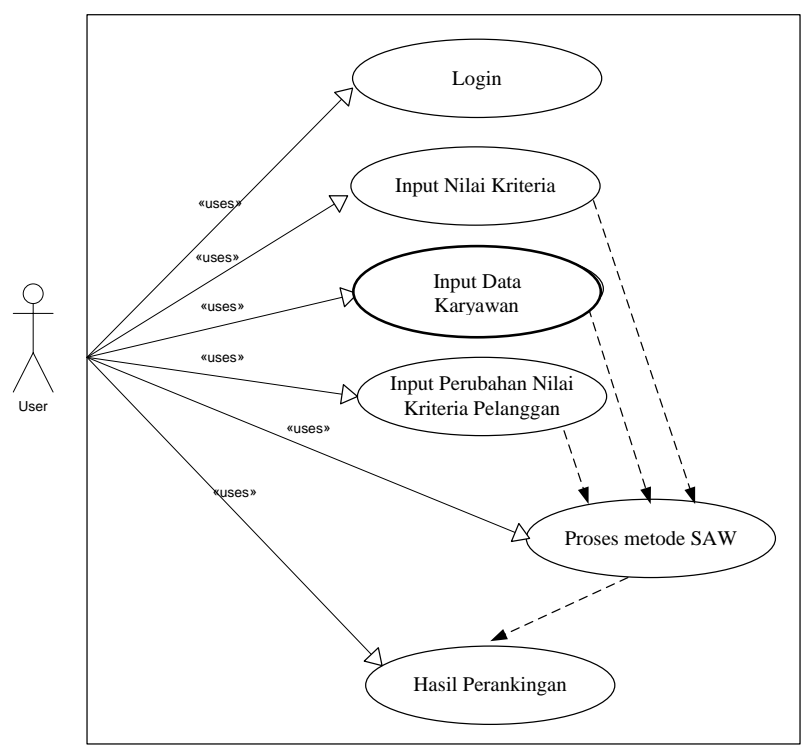

Gambar 2. Use Case

Skenario Use Case untuk pengolahan data

Aktor : User

Tujuan : Masuk untuk mengolah data

Untuk memahami lebih jelas, apa saja yang akan dilakukan oleh user dalam Use Case diagram diatas, maka akan dijelaskan skenario Use Case sebagai berikut:

a. Use Case Login Mengisi Nilai

Nama Use Case : Mengisi Nilai Kriteria Karyawan

Deskripsi : Memungkinkan pengguna untuk mengisi data nilai kriteria dimana nilai kriteria ini merupakan acuan dalam melakukan penghitungan nantinya.

Prekondisi $\quad$ : Pengguna sudah menjalankan aplikasi

Proses :Pengguna terlebih dahulu mengisi data pelanggan dan bobot kriteria

Kondisi Akhir $\quad$ : Aplikasi akan menyimpan data nilai kriteria

b. Use Case Login Mengisi Data Karyawan

Nama Use Case : Mengisi Data Karyawan

Deskripsi : Memungkinkan pengguna untuk mengisi data

Pelanggan dimana data ini merupakan alternatif yang diambil untuk menentukan keputusan.

Prekondisi : Pengguna sudah menjalankan aplikasi

Proses : Pengguna terlebih dahulu mengisi data calon

Pelanggan dan bobot kriteria kemudian mengisi nilai kriteria disetiap Pelanggan.

Kondisi Akhir $\quad$ : Aplikasi akan menyimpan data nilai kriteria 
c. Use Case Login Mendapatkan Hasil Perhitungan

Nama Use Case : : Mendapatkan Hasil Perhitungan

Deskripsi : Memungkinkan pengguna untuk mendapatkan hasil perhitungan dengan mrnggunakan metode SAW

Prekondisi $\quad$ : Pengguna sudah menjalankan aplikasi

Proses : Pengguna terlebih dahulu memilih data karyawan yang akan dinilai lalu sistem akan menghitung penilaian dengan metode SAW.

Kondisi Akhir : Aplikasi akan menghitung dan menunjukkan hasil dari perhitungan

d. Use Case Login Mengambil Keputusan

$\begin{array}{ll}\text { Nama Use Case } & \text { : Mengambil Keputusan } \\ \text { Deskripsi } & \text { : Memungkinkan pengguna untuk mendapatkan } \\ & \text { hasil perhitungan dengan menggunakan metode } \\ & \text { SAW } \\ \text { Prekondisi } & \text { Pengguna sudah mencatat penilaian dari setiap } \\ & \text { Karyawan yang berprestasi } \\ \text { Proses } & \text { Pengguna mencatat semua penilaian yang telah } \\ & \text { dilakukan lalu mengurutkan nilai dari yang } \\ & \text { tertinggi sampai yang terendah. } \\ \text { Kondisi Akhir } & : \text { Pengguna mendapatkan semua penilaian } \\ & \text { pelanggan utama dan dapat mengambil } \\ & \text { keputusan. }\end{array}$

\subsection{Pengujian dan Hasil}

Pengujian yang dilakukan adalah pengujian metode (method testing) dengan menggunakan metode SAW. Metode SAW sebuah kerangka untuk mengambil keputusan dengan efeftif. Pengujian metode berfokus pada tindakan pengguna yang terlihat dan pengguna dapat mengenali output dari sistem, pengujian ini menjalankan sistem pada lingkungan yang aktif dengan menggunakan data yang benar. Pada tahap ini pengujian pada administrator yang memiliki hak akses sepenuhnya pada sistem. Hasil yang di dapat dari sistem ini mampu memberikan keputusan terbaik dalam penilaian prestasi kerja karyawan yang bagus sesuai keinginan

\section{SIMPULAN}

Dengan adanya penelitian ini penulis telah merancang dan membangun suatu sistem pendukung keputusan menggunakan program web dengan menggunakan database $M y S Q L$ serta menggunakan sebagai metode, sehingga dapat membantu pihak pimpinan memberikan suatu informasi tentang penilaian prestasi kerja karyawan yang sesuai dengan keinginannya. Dari hasil pengujian sistem, metode $S A W$, menghasilkan alternaif yang sama dengan perhitungan manual yang dilakukan serta dapat lebih cepat SPK Penilaian Prestasi Kerja karyawan (Agus Perdana Windarto) | 94 
memperoses data dibandingkan dengan pengambilan keputusan yang dilakukan dengan cara tradisional.

\section{DAFTAR PUSTAKA}

[1] Nofriansyah, D, "Konsep Data Mining Vs Sistem Pendukung Keputusan”, Ed.1, Cet.1, Yogyakarta, Deepublish, September, 2014

[2] Fajar Nugraha, Bayu Surarso, Beta Noranita, "Sistem Pendukung Keputusan Evaluasi Pemilihan Pemenang Pengadaan Aset Dengan Metode Simple Additive Weighting (SAW)", Jurnal Sistem Informasi Bisnis 02, On-Line, Http://Ejournal.Undip.Ac.Id/Index.Php/Jsinbis, 2012

[3] Siti Maryam Siregar (1011078), "Sistem Pendukung Keputusan Pemilihan Guru Teladan Di Sma Era Utama Pancur Batu Menggunakan Metode Topsis", Pelita Informatika Budi Darma, Volume IX, Nomor 2, Issn : 2301-9425, Maret 2015

[4] Eltri Jayanti, "Penerapan Metode Simple Additive Weighting Dalam Sistem Pendukung Keputusan Perekrutan Karyawan (Studi Kasus: Pt. Perkebunan Nusantara III Medan)", Pelita Informatika Budi Darma, Volume : Ix, Nomor: 3, Issn : 2301-9425, April 2015

[5] Agus Perdana Windarto, "Implementasi metode topsis dan saw dalam memberikan reward pelanggan," Kumpul. J. Ilmu Komput., vol. 4, no. 1, pp. 88-101, 2017. 